\title{
Accelerating The Global Competitiveness of Nigerian Economy: The Role Of Polytechnic Education
}

\author{
Agu Godswill Agu, Ph.D \\ Department of Marketing , Faculty of Business Administration \\ Abia State University, Nigeria. \\ Godwin 0. Merenini (HRH) \\ Umudibia Autonomous \\ Community, Imo State Nigeria \\ Ebeke Egele Aja Ph.D \\ Department of Marketing, Faculty of Management Sciences \\ Ebonyi State University, Abakaliki, Nigeria.
}

\begin{abstract}
The Global Competitiveness of Nigerian Economy has been ranked poor by the World Economic Forum (WEF) since the past ten years. The country has maintained a threedigit position for about a decade, averaging 114 out of 139 countries and 3.57 on a 7 point scale since the past nine years. Although poor infrastructure, corruption, and access to finance have been identified as the three most problematic factors to business, productivity and global competitiveness of the country, the inability of Nigeria to fully tap from the potentials of polytechnic education which is practical and productive oriented has contributed in worsening the country's competitive ranking globally. This study x-rayed Nigeria's ranking in the World Economic Forum's Global Competitiveness Index from 2007 to 2015 and adopted the Porter's Diamond Model in explaining the role of polytechnic education in enhancing Nigeria's global competitiveness. Evidence from the WEF 2015/2016 report reveals that Nigeria remains one of the poorly ranked economies in terms of global competitiveness and productivity. The paper provides an insight into the untapped potentials of polytechnic education in Nigeria and how the country can leverage it to overcome economic recession and accelerate its global competitiveness and productivity.
\end{abstract}

Key Words: Polytechnic Education, Global Competitiveness Index, National Competitiveness, Porter's Diamond Model.

\section{INTRODUCTION}

It is no longer news that Nigerian economy had remained in recession since the early months of 2016, having experienced two consecutive quarters of declining growth; which usually defines recession. The economy has remained a night mare to many of its citizens. Economic analysts and other research experts had earlier lamented the speedy sliding of the economy into economic recession with its attendant consequences (Emefiele, 2015; Agbakoba, 2016; Omoh, 2015; Nduka, 2015). The macroeconomic indicators, as realities of the Nigerian economy are heavy pointers to the downward trend in real economic growth, the rebasing of GDP computation and International Monetary Fund's ranking of the economy as the 'biggest' in Africa notwithstanding. Judging from the noticeable economic indicators such as inflation rate; which stood at $17.9 \%$ for September 2016, poverty level which has increased from $60 \%$ in 2015 to $72 \%$ as at August 2016, unemployment rate which had jumped from $12.1 \%$ to $13.3 \%$ as at August 2016 and insecurity which had penetrated the oil reach Niger Delta region, there 
is no doubt that Nigeria is struggling with economic recession (NBS, 2016; Sanusi, 2016; Fitche International, 2016; Ngige,2016; Adeosun, 2016; BBC News, 2016; Udo,2016).

As a global entity, Nigerian economy is monitored by world bodies and report of the progress or otherwise, is released periodically for corrective measures to be adopted. The Global Competitiveness Index (GCI) is one of the tools used by the World Economic Forum to keep nations awake to the need for sustained inclusive economic growth. It is an annual assessment of the drivers of national competitiveness. The popularity of the competitiveness benchmarking at the country level is an indicator of growing interest in comprehensive frameworks and data for competitiveness-related decision-making (Ambastha \& Momaya, 2016). The GCI has been singled out since 1979 as the world's most comprehensive data source for cross-country comparison of factors affecting economic competitiveness and growth (NCCN, 2015).

Porter $(1990,20007)$ rightly observed that the only meaningful concept of competitiveness at the national level is productivity. He also noted that productivity is the value of output produced by a unit of labour or capital. It depends on both the quality and features of products (which determine the prices that they can command) and the efficiency with which they are produced. Nigeria as an economy has remained less competitive in the global ranking since the 2007 updated methodology to Global Competitiveness ranking when compared with other African countries such as Mauritius, South Africa and Cote d'Ivoire. In view of this scenario, the following questions are apt:

1. What should be done to re-enforce the competitiveness of Nigerian economy as a global brand?

2. What role can Polytechnic education play In improving the global competitiveness of the country?

3. What policy measures are required by the country to be re-aligned for stronger competitiveness?

4. What benefits does Nigeria stand to gain if perfectly re-aligned to the global competitiveness landscape?

Providing answers to these questions is the thrust of this paper.

\section{REVIEW OF RELATED LITERATURE The Concepts of Polytechnic Education and Polytechnic Graduates}

Polytechnic education is an arm of vocational training education (VTE). According to the National Policy on Education (2004), VTE refers to "Those aspects of the education process involving, in addition to general education, the study of technologies and related sciences and the acquisition of practical skills, attitudes, understanding and knowledge of occupation in various sectors and social life". The emphasis of Polytechnic and other vocational and technical institutions is on acquisition/attainment of practical skills and knowledge and their applications (Oni, 2007; Bayelo, 2007) and gainful employments (Punding, 1994). Besides, Bayelo (2007) captured the three key components/ benefits of VTE thus: Attitude to survival, not dependent (Heart); Skills for self-reliance (Hands); and Knowledge to subdue (Head).

The goals of VTE as captured by NPE (2004) are: To provide trained manpower in the applied sciences, technology and business particularly at the craft, advanced craft and technical levels, to provide technical knowledge and vocational skills for agriculture, commerce and economic development and to give training and impart the necessary skills to individuals who shall be self reliant economically. Specifically, Polytechnic education is seen as that aspect of 
education which leads to the acquisition of practical and applied skills as well as basic scientific knowledge. While quoting the National Council on Education, Yabin in Onwuka (2010) sees Polytechnics as technical institutions offering mostly post secondary technical education programmes outside the university, leading to the awards of Diploma and Higher Diploma Certificates. It is a consensus among scholars that no nation can achieve competitive advantage and improved productivity, growth and development without a cadre of well trained technologists, technicians and engineers; the real products of Polytechnic and VTE institutions

Polytechnic education is however, faced with the following impediments which have made it difficult for it to achieve the much expected impact in Nigeria (Oko, 2014; African Union, 2007; Onwuka, 2010; Yakubu, 2005; Federal Ministry of Education, 2006): wrong conceptualization and perception of polytechnic education as dumping ground for those who could not secure admission into the universities, discrimination by the government, the society and employers in terms of funding, employment benefits, promotions and emoluments, inadequate and obsolete analogue workshops, laboratories and teaching aids, poor linkage between formal and non-formal vocational and technical education, outdated curriculum that can hardly attain modern polytechnic education goals, poor industry-institution linkages, poor staffing and employment of non-qualified lecturers, widening teacher-student ratio, unethical behaviour among staff and low tempo of research and staff training programmes.

The polytechnic graduates are the offspring or real products of polytechnics. They are those who have acquired sound technical and technological skills and knowledge required to drive the growth and competitiveness of the Nigerian economy. The graduates cut across such disciplines as Agriculture, Architectural Technology, Business Management, Banking and Finance, Marketing, Civil Engineering, Computer Science, Food Technology, Public Administration, Science Laboratory Technology, Electric and Electronic Engineering, Mass Communication, Surveying, Regional Planning, etc. It is on record globally, that polytechnics produce the highest number of graduates who are self employed and those who are capable of creating employment opportunities for different classes of workforce. This contributes to poverty reduction and improved standard of living. One of the key differences between polytechnics and universities is the amount of practical versus theory. Polytechnics have a strong background on how to bring "learning by doing" into the classroom. They try to align graduate skills with what the global market wants.

This therefore demonstrates that there is a link between polytechnic education and national productivity/competiveness. Before now in Nigeria, the polytechnics were well equipped for practical teachings, less populated and staffed with qualified professionals. Industrial trainings (attachments) were thoroughly supervised, given the manageable number of students to be supervised by a lecturer. Today, polytechnics have remained a near dumping ground for students who could not gain admission into the universities and who have no interest or zeal for practical education. Overpopulation, where a classroom of one lecturer will be provided for close to a thousand students, has remained the order of the day in an attempt by the administrators to increase internally generated revenue. The implication of the situation is the presence of large number of polytechnic graduates who are job seekers instead of entrepreneurs.

\section{The Concept of National Competitiveness/Theoretical Framework}

Competitiveness is seen as the set of institutions, policies and factors that determine the level of productivity of an economy which in turn sets the level of prosperity that the country can earn. Growing body of empirical literature shows that differences in productivity are the main 
determinants of cross-country prosperity levels (World Economic Forum, 2011). How to increase productivity remains a key question that needs to be answered in any economy. Porter (1990) disclosed that a nation's competitiveness depends on the capacity of its industry to innovate and upgrade. He equally summarized the meaning of productivity thus:

'The prime determinant of a nation's long run standard of living, the root cause of national per capita income, major determinant of employee wages and return to capital investment'. To sustain productivity, an economy must upgrade itself by raising product quality, adding desirable features, improving product technology, boosting production efficiency, developing necessary capability to compete in more sophisticated industry systems where productivity is generally high, developing compatibility to compete in entirely new sophisticated industries (porter, 1990).

This paper hinges on Porter's Diamond Model. The key determinants of national competitiveness are captured by Porter (1990) thus:

1. Factor Conditions: the nation's position in factors of production, such as skilled labour or infrastructure, necessary to compete in a given industry.

2. Demand Condition: the nature of home-market demand for the industry's goods and services.

3. Related and Supporting Industries: the presence or absence in the nation of supplier industries and other related industries that are internationally competitive.

4. Firm Strategy, Structure and Rivalry: the conditions in the nation governing how companies are created organized and managed as well as the nature of domestic rivalry.

These determinants, according to Porter (1990) create the national environment in which companies are born and learn how to compete. A look at these key determinants reveals that polytechnic graduates can significantly influence the trend of these national competitive drivers. First, polytechnic graduates are among the skilled labour of the nation that determines the productive capacity of the nation. They are seen in virtually all the sectors of the economy. Second, through their trainings, polytechnic graduates are among the think-tanks in various organizations that map out strategies to enhance the demand of Nigerian made brands (goods and services). Third, a good number of the indigenous small and medium scale organizations that are directly or indirectly involved in one form of international marketing or the other are owned and managed by polytechnic graduates. Finally, the polytechnic graduates are key decision-makers and participants in several governmental legal formulations on business operations, though they may not be lawyers. In view of this all-inclusive role of polytechnic graduates, it is our view to amend Porter's diagrammatic representation of the determinants of national competitiveness to capture the relevance of polytechnic graduates thus: 


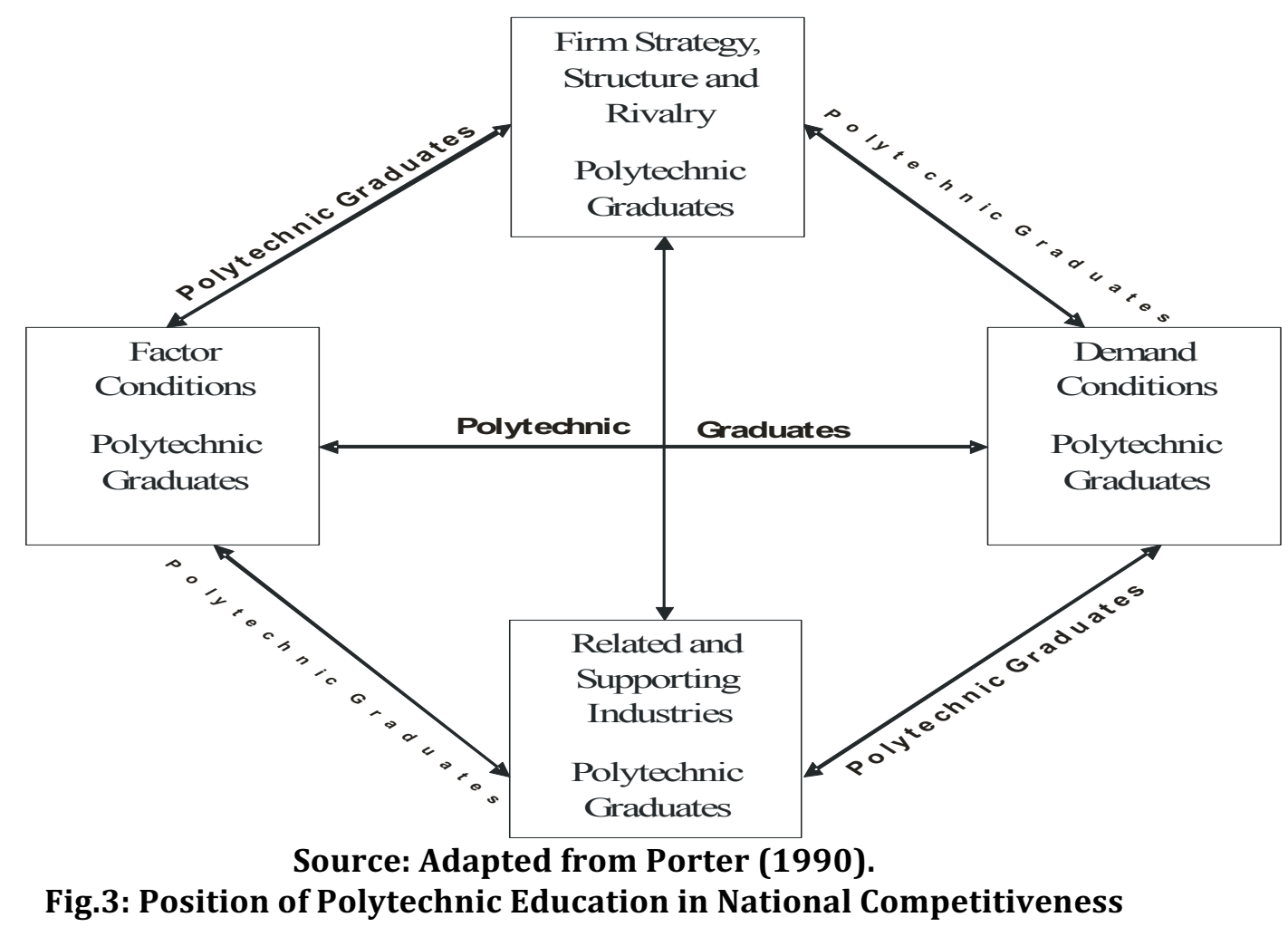

\section{THE GLOBAL COMPETITIVENESS INDEX}

Global Competitiveness Index (GCI) is an annual assessment of drivers of productivity. Report of $2015-2016$ is the $36^{\text {th }}$ edition in the series. This study based its explanation and definition on the updated methodology to GCI calculations since 2007. The GCI combines 114 indicators that capture concepts that are relevant in productivity discuss. However, they are grouped into 12 pillars: institution, infrastructure, macroeconomic environment, health and primary education, higher education and training, goods and market efficiency, labour market efficiency, financial market development, technology readiness, market Size, Business Sophistication, Innovation( WEF, 2014). Table 1 shows the three stages on which economies are expected to pass through; from the least to the highest, desirable stages. Just as countries are generally grouped as third world, second world and first world nations, the GCR sees countries as factor driven, efficiency driven and or innovation driven. The lower table captures the income thresholds for countries at different stages of development in addition to the weights. 


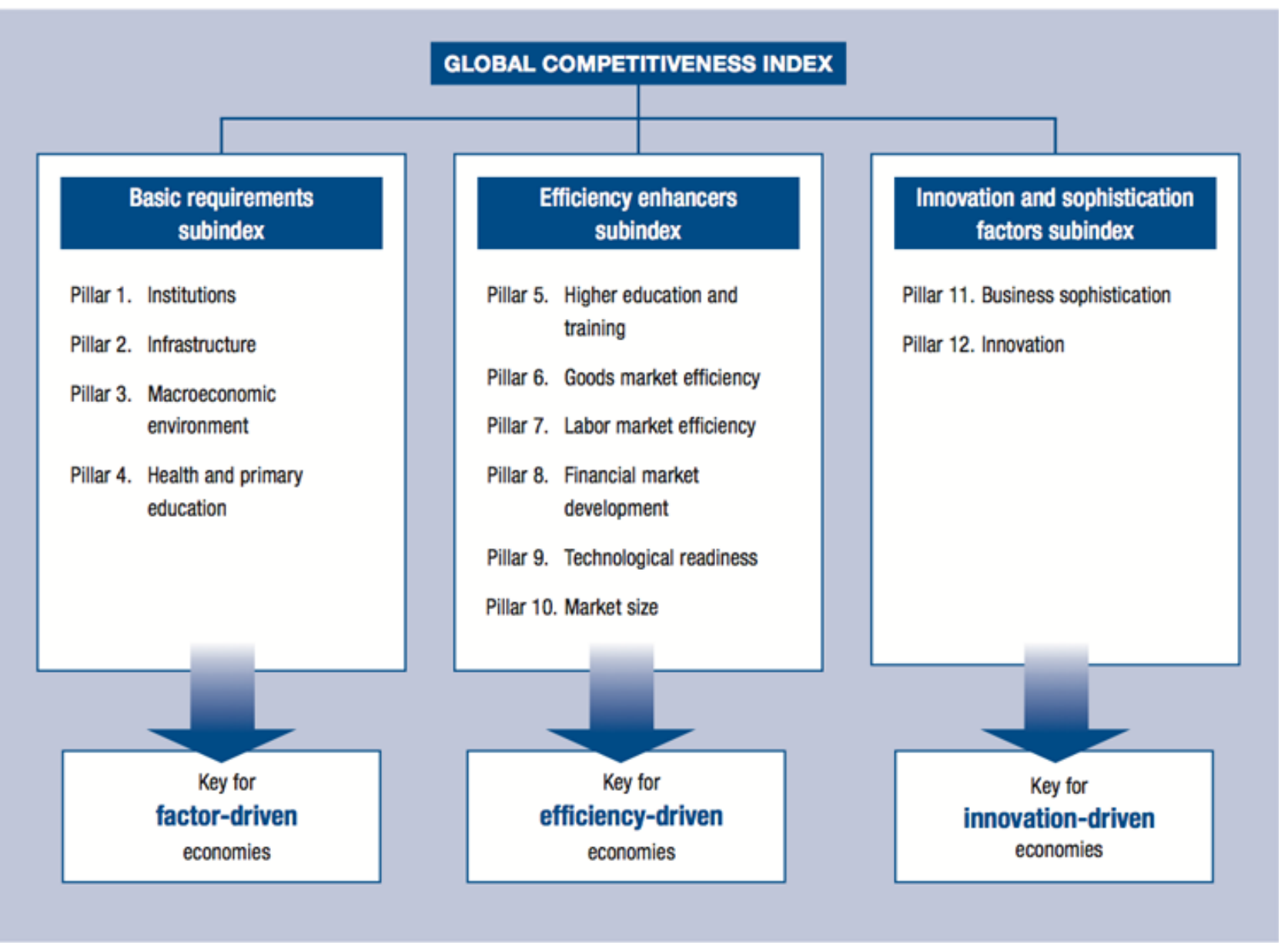

Source: WEF, 2013,2014 and 2015. Fig. 4: The Twelve Pillars and Their Sub- indexes.

The 12 pillars are summarized under three sub-indexes, each carrying different weight for economies at different stages of development as shown below:

\begin{tabular}{|c|c|c|c|c|c|}
\hline & \multicolumn{5}{|c|}{ STAGE OF DEVELOPMENT } \\
\hline & $\begin{array}{c}\text { Stage 1: } \\
\text { Factor-driven }\end{array}$ & $\begin{array}{c}\text { Transition from } \\
\text { stage } 1 \text { to stage } 2 \\
\end{array}$ & $\begin{array}{c}\text { Stage 2: } \\
\text { Efficiency-driven }\end{array}$ & $\begin{array}{c}\text { Transition from } \\
\text { stage } 2 \text { to stage } 3\end{array}$ & $\begin{array}{c}\text { Stage 3: } \\
\text { Innvation-driven }\end{array}$ \\
\hline GDP per capita (US\$) thresholds* & $<2,000$ & $2,000-2,999$ & $3,000-8,999$ & $9,000-17,000$ & $>17,000$ \\
\hline Weight for basic requirements & $60 \%$ & $40-60 \%$ & $40 \%$ & $20-40 \%$ & $20 \%$ \\
\hline Weight for efficiency enhancers & $35 \%$ & $35-50 \%$ & $50 \%$ & $50 \%$ & $50 \%$ \\
\hline Weight for innovation and sophistication factors & $5 \%$ & $5-10 \%$ & $10 \%$ & $10-30 \%$ & $30 \%$ \\
\hline
\end{tabular}

\section{X-RAYING NIGERIA'S 2015/2016 GCI RANKING/PERFORMANCE}

1. Nigeria is yet to achieve a meaningful progression from its ranking over the years as it has remained amongst the poorly ranked countries since 2007 averaging 114 out of 139. Nigeria has maintained a-three-digit position in the last six years, averaging 114 out of 139 countries and an average of 3.57 in the last nine years.(See table 2). 
Table 2: Nigeria's position from 2007 to 2015 is displayed on the table below:

\begin{tabular}{|l|l|l|l|}
\hline Year & Position & Number of Countries & Score Over 7 \\
\hline 2007 & 95 & 131 & 3.69 \\
\hline 2008 & 94 & 134 & 3.81 \\
\hline 2009 & 99 & 133 & 3.65 \\
\hline 2010 & 127 & 139 & 3.38 \\
\hline 2011 & 127 & 142 & 3.45 \\
\hline 2012 & 115 & 144 & 3.67 \\
\hline 2013 & 120 & 148 & 3.57 \\
\hline 2014 & 127 & 144 & 3.44 \\
\hline 2015 & 124 & 140 & 3.46 \\
\hline Average & $\mathbf{1 1 4}$ & $\mathbf{1 3 9}$ & $\mathbf{3 . 5 7}$ \\
\hline
\end{tabular}

Table 3: Comparing Nigeria with Selected African Countries

\begin{tabular}{|l|l|l|l|l|l|}
\hline Factor/Country & Nigeria & $\begin{array}{l}\text { South } \\
\text { Africa }\end{array}$ & Cote d'Ivoire & Ghana & Kenya \\
\hline GCI Ranking & $124^{\text {th }}$ & $49^{\text {th }}$ & $91^{\text {st }}$ & $119^{\text {th }}$ & $99^{\text {th }}$ \\
\hline Population & 173.9 & 54.0 & 22.7 & 26.2 & 42.9 \\
\hline GDP (US \$ in Billion) & 573.7 & 350.1 & 34.0 & 38.6 & 60.8 \\
\hline $\begin{array}{l}\text { Per Capita income (US } \\
\text { \$) }\end{array}$ & 3,298 & 6,483 & 1,495 & 1,474 & 1,416 \\
\hline Score & 3.46 & 4.39 & 3.96 & 3.58 & 3.85 \\
\hline Basic Requirements & 136 & 85 & 102 & 127 & 116 \\
\hline Efficiency Enhancers & 81 & 41 & 96 & 95 & 73 \\
\hline $\begin{array}{l}\text { Innovation and } \\
\text { Sophistication }\end{array}$ & 114 & 36 & 73 & 65 & 42 \\
\hline Stage of Development & $\begin{array}{l}\text { Transition } \\
\text { from } \\
\text { stage 1 to } \\
\text { stage 2 }\end{array}$ & $\begin{array}{l}\text { Stage 2: } \\
\text { Efficiency } \\
\text { Driven }\end{array}$ & $\begin{array}{l}\text { Stage 1: Factor } \\
\text { Driven }\end{array}$ & $\begin{array}{l}\text { Stage 1: } \\
\text { Factor } \\
\text { Driven }\end{array}$ & $\begin{array}{l}\text { Stage } 1: \\
\text { Factor } \\
\text { Driven }\end{array}$ \\
\hline
\end{tabular}

Source: WEF (2015)

2. Poor infrastructure, corruption and access to finance are the three most problematic factors to business in the country. This shows that Nigeria is still struggling to achieve the basics as it was ranked $136^{\text {th }}$ out of 140 countries in the basic requirements. Better performance was achieved in the efficiency enhancers stage as the country occupies the $81^{\text {st }}$ position out of 140 countries. This is largely owing to our large market size and rebased GDP. Very poor performance again at the innovation and sophistication stage as the country came $114^{\text {th }}$ out the 140 countries. (table 6). The country's best performance was in technology readiness having been ranked $25^{\text {th }}$ globally with a score of 5.07 .

3. The country has managed to wriggle out of the first stage ((factor driven) to the "the transition from stage one to stage two" position. However, this is still less than South Africa's position as an "Efficiency driven" economy (stage two). Table 4 shows that Nigeria settled among the last ten poorly rated African countries in the 2015 ranking, Scoring 3.46 as against 4.44 scored by the first and highly rated African country; Mauritius which was ranked $46^{\text {th }}$ in the world and followed by South Africa which was ranked $49^{\text {th. }}$ ( See table 4 ) 
4. Though away from the first stage in the ranking, Nigeria still has serious infrastructural set back in terms of all-round transport infrastructure (rail, road, air, sea and pipeline), energy infrastructure ( electricity supply and rate). An improvement was noticed in ICT infrastructure in terms of mobile phone subscription and internet usage. . (See figure 10).

5. As the highly ranked African Economies, Mauritius and South Africa drew their strength from "increased uptake of ICTs, especially higher internet bandwidth and improvements in innovation (WEF, 2015).

6. Nigerians fortunate migration from a "factor driven" economy to a "transiting economy to efficiency driven" is largely owing to the rebasing of its GDP computation which does not reflect the reality on ground and hence, not an inclusive growth progression as standard of living of the citizens still remains very low.

\section{ACCELERATING NIGERIA'S GLOBAL COMPETITIVENESS: THE WAY FORWARD}

Seeing that our economy is besieged with an array of problems hindering it from being aligned to global competitiveness, what role has the polytechnics got to play? And what institutional and policy frameworks should the nation put in place? These strategies are recommended:

1. As products of a practical-oriented educational institution, polytechnic graduates are encouraged to be entrepreneurs, seeking to enlarge the scope of operation beyond the soil of Nigeria by internationalizing their businesses. This is a factor that has kept the first ten highly competitive economies (Switzerland, Singapore, United States, Germany, Netherlands, Japan, Hong Kong SAR, Finland, Sweden and United Kingdom) at the forefront.

2. The Buhari's Administration is encouraged to continue with the fight against corruption, but in a very transparent manner as corruption has remained a cankerworm to the global competitiveness rating of the nation over the years.

3. Again, poor infrastructural facilities (road, power, health, etc) and poor access to finance should be tackled. Thanks to the present effort of the Federal Government and some state Governors. However, more is still expected as research has shown that more than $70 \%$ of our local roads, where the raw materials needed for industrial productivity are sourced, have remained largely in poor condition (Ogwo and Agu, 2015).

4. The polytechnics as the engine room of economic development and productivity should see Information and Communication Technology (ICT) as a base for every area of specialization. While demonstrating the position of technology in the business external environment, Agu (2015) proposed a new model known as "TEPLEDIC" which puts technology at the hub of every business. To actualize this, the diagram below could serve as a guide. 


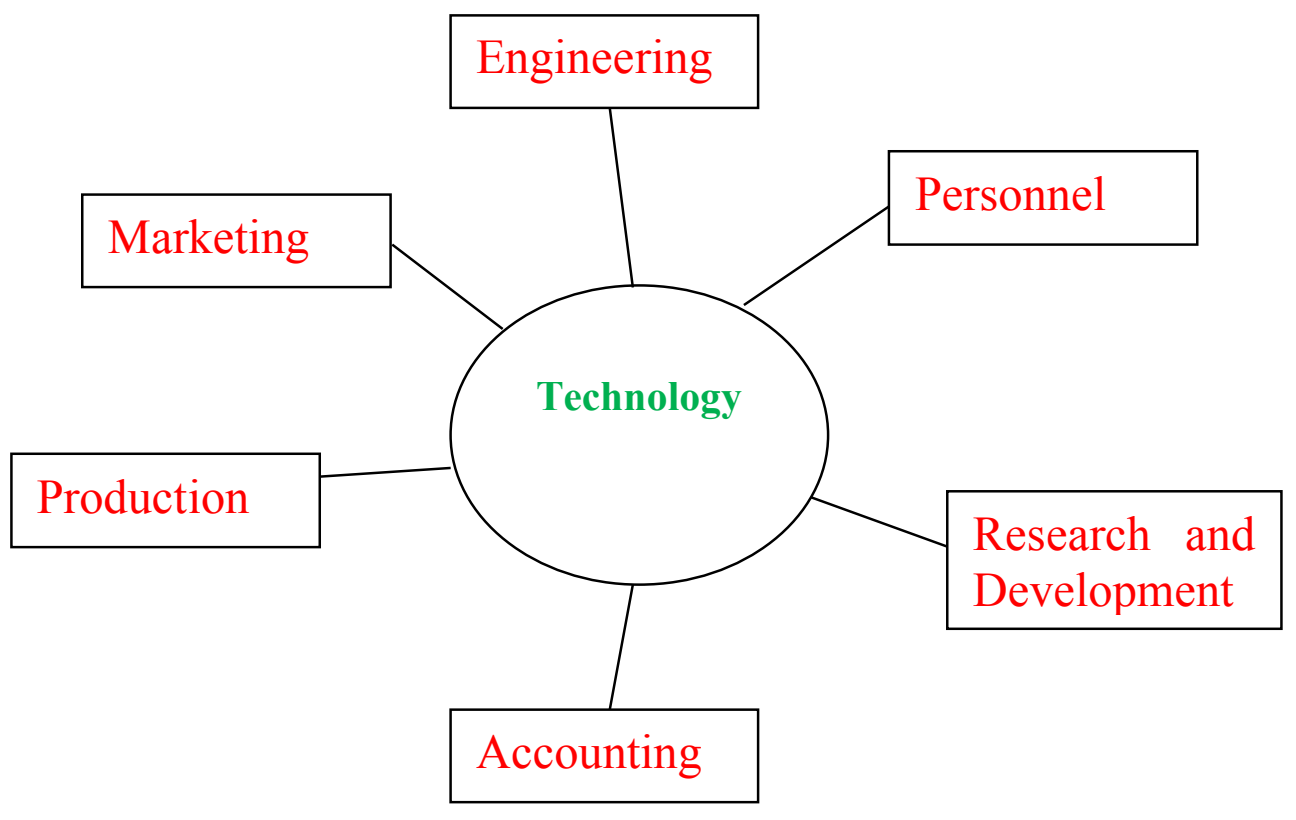

Being technologically conscious is a sure way to innovativeness which is the climax of global competitiveness.

5. Polytechnics, entrepreneurs and the government are encouraged to benefit from the large market size of Nigeria to improve productivity. To do this effectively, link between the polytechnics and (Industrial Clusters, Mechanic Villages and Electronic/Electrical \& Automobile Markets, etc) is advocated. Linking town and gown in this respect will ensure the researches, findings and inventions of the polytechnics are harnessed and brought to the public through this innovative partnership, while practical engineering and electronics assignments can be carried out by students

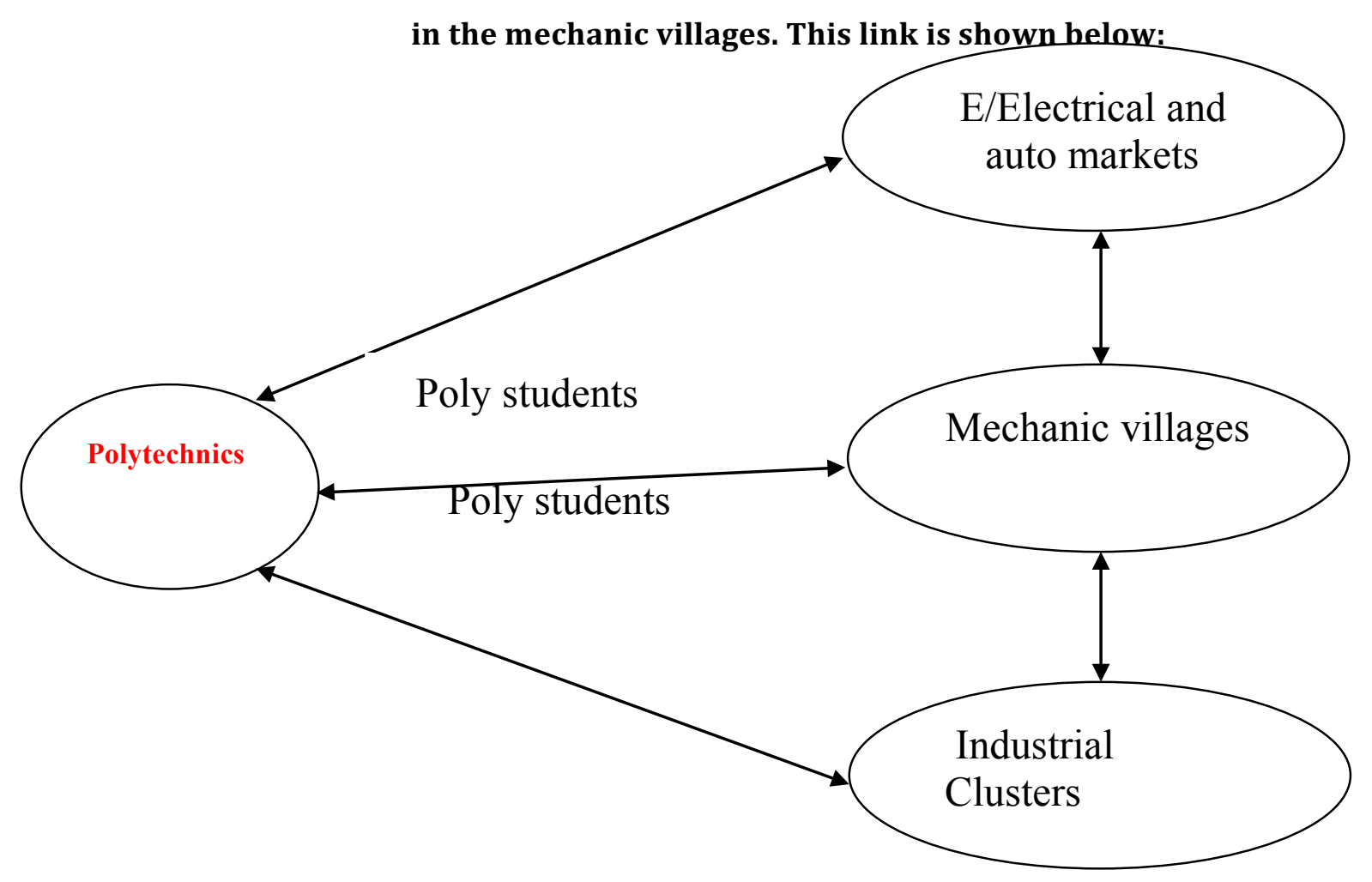

Source: Researchers' proposition, (2016). 
6. The government is encouraged to implement legislations that will enhance the status, image and reputation of polytechnics and polytechnic graduates in the labour market and other institutions. This will elevate their morale to increase their productivity as they are the majority in the productive sector of the economy which counts most in global competitiveness ranking.

7. To ensure a favourable global competitiveness ranking by the end of 2016, the Nigerian government and indeed all stakeholders in the economy should assist in fighting and saying no to corruption, injustice and hatred as well as other vices that tend to undermine the spirit of unity that will lead to sound global competitiveness. This requires sound institutions such as the judiciary, the parliamentarians ( law makers at the state and federal levels), INEC, the Police force, the military, EFCC, ICPC, CBN, NSE, customs, immigration, FRSC, Nigerian Ports Authority, Power Holding Company etc that will uphold global best practices. The soundness of these institutions will affect positively the actualization of best results in the rest of the pillars. Incorporating the principles and standards of polytechnic education in these institutions will help to achieve this.

8. Nigeria must step up its efforts to re-accelerate economic competitiveness through enhanced productivity. And this would be possible when polytechnic and vocational graduates live up to the mandate of their education because the link between global competitiveness and quality of polytechnic graduates in an economy is obvious.

\section{References}

Abubaka, M. S. (2008). “Quality Assurance Processes and Procedures in Nigerian Polytechnics: Addressing New Challenges". A Paper Presented at the Orientation Retreat for Governing Council and Principal Officers of Federal Polytechnics Held in Kaduna.

Adeosun, K (2016) “Nigerian Economy is in Recession: We will turn the Corner in September”. This Day , July 22.

African Union (2007). "Strategy to Revitalize Technical and Vocational Education and Training an Africa: Final Draft". (www.31/VETlengh.com).

Agbakoba, O. (2016). "Nigeria is Sliding into Economic Recession Under Buhari's Watch”. Vanguard, March 13.

Aghuli, N. O. (2002) "Rebranding Vocational and Technical Education for Better Performance and Productivity in the Nigerian Economy". Journal of Vocational and Technical Education, Vol. 3 No. 1.

Agu, G. A. (2015). “Innovation and Brand Management Strategies”. Owerri: Gandic Avan Global Press.

Ambastha, A. and Momya, K. (2016). “Competition of Firms: Review of Theory, Frameworks and Models” Indian Institute of Technology.

Babagide, K. (2016). “Slowdown in GDP Persisted in First Quarter - CBN Report”. Vanguard, 4.

Bayelo, T. D. (2007). “Training and Technical Education in Nigeria” (www.ags.org.uk) accessed 21/4/2016.

BBC News (2016) “Nigerian Economy Slips into Recession”. August 31.

Ebhotenhen, S. B. and Uma, S. S. (2008) "Repositioning Polytechnic Education for Federal Development in the New Millennium" Auchi Poly News, Vol. 1. No. 1.

Fitche International Report (2016) “Nigeria's Poverty Level Index Hits 72\% in 2016”. May 22.

National Bureau of Statistics (2016) “Nigeria’s Unemployment Rate Rises to 13.3\%”. August 31.

Nduka, C. (2015). “Nigeria's Economy may Slip into Recession: CBN Warns” Thisday,, September 23.

Ogwo, E. O. and Agu, G. A. (2015) “Transport, Infrastructure, Manufacturing Sector Performance and the Growth of GDP in Nigeria: 1999 - 2014”. AJEST Journal, Vol. 2 No. 3.

Oko, O. O. (2010). Polytechnic Education in Nigeria: Problems and Prospects. In Technology, Education, Administration and National Development. A Book of Reading in Honour of Engineer Onyekwere, I. N.

Omoh, G. (2015) “Nigeria’s Economy Heading for Recession”. Vanguard, September 2.

Oni, C. S. (2007). "Vocational Nigerian Education”. Journal of Social Education, Vol. 12 (2), 147 - 50.

Porter, M. (1990) The Competitive Advantage of Nations. New York: The Free Press. 
Agu, A. G., Merenini, G. O., \& Aja, E. E. (2017). Accelerating The Global Competitiveness of Nigerian Economy: The Role Of Polytechnic Education. Advances in Social Sciences Research Journal, 4(17) 120-130.

Sanusi, L.S (2016) “How Nigerian Government Caused Economic Recession”. Premium Times, September 2.

World Economic Forum “2015 - 2016 Global Competitive Index Report”. www.wef.org.

Yakubu, N. (2005). “Current State of Polytechnic Education in Nigeria”. A Paper Presented at a Conference on Reform and Revitalization of the National Science and Technology Innovation System: UNESCO/N 